\title{
INCORPORATING THE UNITED NATIONS PROTOCOL ON TRAFFICKING IN PERSONS IN THE MALAYSIAN LEGAL FRAMEWORK
}

\author{
Khairil Azmin bin Mokhtar* \\ Zuraini binti Ab Hamid ${ }^{* *}$
}

\begin{abstract}
The international framework of anti-human trafficking has become the main guiding framework for countries around the globe in combating the crime. The issue of human trafficking was brought to global attention mainly by the Protocol to Prevent, Suppress and Punish Trafficking in Persons especially Women and Children. The UN Protocol provides a standard approach to state parties in combating human trafficking. The approach is known as "3Ps" model which aim to prevent the crime, to protect the victim and to prosecute the perpetrator. In spite of the creation of AntiTrafficking National Action Plan (NAP) in 2012 and the passing of the Anti-Trafficking in Persons and Anti-Smuggling of Migrants Act 2007 (ATIPSOM 2007) by the Malaysian government in the US Department of State Trafficking in Persons Report 2014 (TIP) it is stated that "3Ps" approach is lacking in the Malaysian legal framework. This paper analyses whether Malaysia's legal response through its Anti Trafficking in Persons and Smuggling of Migrants Act 2007 and other relevant legislation are in compliance with the Protocol. In this study it is found that there are many aspects of rights and protection still wanting within the legal framework of human trafficking in the country. Reformation of Malaysia's legal framework in combating human trafficking is much needed to ensure its compliance with the international framework and in order for the local enforcement agencies to be more successful in combating the crime.
\end{abstract}

Keywords: human trafficking, international framework, United Nations, "3Ps" model.

Associate Professor, Department of Civil Law, Ahmad Ibrahim Kulliyyah of Laws, International Islamic University Malaysia, P.O. Box 10, 50728 Kuala Lumpur, Malaysia. E-mail: ka_mokhtar@iium.edu.my.

** Assistant Professor, Department of Legal Practice, Ahmad Ibrahim Kulliyyah of Laws, International Islamic University Malaysia, P. O. Box 10, 50728 Kuala Lumpur, Malaysia. E-mail: zurainihamid@iium.edu.my. 


\title{
MENGGABUNGKAN PROTOKOL PERTUBUHAN BANGSA- BANGSA BERSATU MENGENAI PEMERDAGANGAN ORANG DALAM KERANGKA PERUNDANGAN MALAYSIA
}

\begin{abstract}
ABSTRAK
Rangka kerja antarabangsa berkaitan jenayah pemerdagangan manusia telah menjadi garis panduan utama bagi negara-negara di seluruh dunia dalam memerangi jenayah tersebut. Isu pemerdagangan manusia ini telah dibawa ke perhatian semua pihak secara global terutamanya oleh Protokol untuk Mencegah, Menyekat dan Menghukum Pemerdagangan Orang terutamanya Wanita dan Kanak-kanak. Protokol TIP PBB ini menyediakan pendekatan yang efektif kepada kerajaan dalam memerangi jenayah pemerdagangan manusia. Pendekatan ini dikenali sebagai model "3P" yang bertujuan untuk mencegah jenayah pemerdagangan manusia, melindungi mangsa dan mendakwa pelaku jenayah ini. Artikel ini membuat analisa sama ada tindak balas Malaysia melalui undang-undang terutamanya melalui Akta Anti Pemerdagangan Orang dan Penyeludupan Migran 2007 (ATIPSOM 2007) dan aktaakta sokongan lain selaras dengan Protokol TIP PBB ini. Walaupun Rancangan Tindakan Anti Pemerdagangan Negara (NAP) telah dirangka pada tahun 2012 dan Akta Anti Pemerdagangan Manusia dan Penyeludupan Migran 2007 diluluskan, Laporan Pemerdagangan Manusia 2014 (TIP) oleh Jabatan Negara Amerika Syarikat menyatakan bahawa terdapat kekurangan dalam pematuhan model " $3 \mathrm{P}$ " dalam rangka kerja perundangan Malaysia. Kajian ini mendapati bahwa masih terdapat ruang penambahbaikan terhadap hak dan perlindungan yang diperlukan dalam kerangka perundangan pemerdagangan manusia di negara ini. Satu reformasi perlu dilakukan terhadap kerangka perundangan Malaysia dalam memerangi jenayah pemerdagangan manusia demi memastikan pematuhannya dengan kerangka antarabangsa dan bagi membolehkan agensi penguatkuasaan tempatan menjadi lebih efektif dalam memerangi jenayah tersebut.
\end{abstract}

Kata kunci: pemerdagangan manusia, kerangka kerja antarabangsa, Pertubuhan Bangsa-Bangsa Bersatu, model "3P" 


\section{INTRODUCTION}

Most people assume that human slavery has already ended and it is a thing of the past. On the contrary, statistics have proven that there are more enslaved people now than 200 years ago. Slavery is a very serious issue because it involves both state and human security and undermines democratic value. ${ }^{1}$ Modern day slavery is a global phenomenon and poses a real threat in all countries including Malaysia. It is closely associated with human trafficking. The crime of human trafficking is by nature a transnational organized crime, the commission of which cuts across national borders. Malaysia is no exception. In the US State Department's the Trafficking in Persons Report, it is stated that internal trafficking may take place in the forms of force labor, prostitution and forced marriage. ${ }^{2}$ The success rate in combating human trafficking is different from one country to another. For instance, in the report, Australia is at Tier $1^{3}$ while Indonesia and Singapore are in Tier 2 in 2015. The tier position and achievement of the countries are dependent on their extensive efforts in combating the crime of human trafficking, coupled with compliance with the international legal framework.

This article examines the response by the Government of Malaysia to the human trafficking issue. It will begin with elaboration of the international legal framework on the issue together with the "3Ps" approach to the problem, followed by an assessment on the efforts made by Malaysia to combat the crime of human trafficking. Efforts by the authority shall be examined to determine whether they are in compliance with the "3Ps" approach and to measure their effectiveness. Areas that require attentions from the relevant authorities and the need for further improvement are also highlighted. The views and recommendations at the end of the paper may require legislative and policy reform.

Anna Jonsson, "Human trafficking and human security in the Baltic Sea region," in Human Trafficking and Human Security, ed. Anna Jonsson. (Routledge Taylor \& Francis Group, 2005), 7.

2 U.S Department of State's. "Trafficking in Persons Report June 2005." Washington, DC: Department of State, 2005.

3 "Trafficking in Persons Report July 2015," U.S Department of State, accessed Nov 29, 2015, https://www.state.gov/documents/organization/245365.pdf. 


\section{INTERNATIONAL LAW APPROACH IN COMBATING HUMAN TRAFFCIKING}

In 2000, a comprehensive discussion among the international communities on the issues regarding human trafficking and smuggling of migrants has resulted to the adoption of the United Nations Convention on Transnational Organised Crime (UNCTOC) which is also known as the Palermo Convention. ${ }^{4}$ The main protocol introduced in the Palermo Convention which is directly related to human trafficking is the Protocol to Prevent, Suppress and Punish Trafficking in Persons, Especially Women and Children (hereafter referred to as "the Protocol"). The protocol has become a key tool in the fight against human trafficking where it supplements the UNCTOC and is a legally binding global instrument that defines trafficking in persons. In line with the protocol, about (134) countries and territories worldwide have now criminalised all or most forms of trafficking. ${ }^{5}$ The protocol has strengthen the trafficking laws by providing a workable framework for the "3Ps" approach to combat human trafficking. The "3Ps" model is aimed at preventing human trafficking, protecting the victim of trafficking and prosecuting the perpetrator.

\section{"First P": Prevention of Human Trafficking}

Prevention is the foundation in combating human trafficking at the earliest stage. The method of prevention comprised of two types: long term and short term.

The short term method is implemented by conducting public awareness campaign. The public will be educated with information relating to the crime which touches on topics relating to potential victims and source and destination countries for human trafficking.

4 "United Nations Convention against Transnational Organised Crime and the Protocols Thereto," United Nations Office on Drugs and Crime, accessed Nov 19, 2013, http://www.unodc.org/unodc/treaties/CTOC/.

5 Gyles-McDonnough. "Keynote Address" (paper presented at the International Conference on Trafficking, for the World Youth Foundation, Malacca, September 3-7, 2013).

6 Sanja Milivojevic and Marie Segrave, "Responses to sex trafficking: gender, boarder and home", in Trafficking and Human Rights: European and AsiaPacific Perspectives, ed. Leslie Holmes (Edward Elgar Publishing Ltd, 2010), 45 . 
The aim of the campaign is to warn the danger of human trafficking and to educate citizens on how to identify the victims of human trafficking. ${ }^{7}$ In Indonesia, such a campaign includes a module which covers the risks of migration and the rights of migrants in foreign countries.

The long-term method is adopted through implementation of laws. Nowadays, policy and law in a country are considered as among the effective tools in combating human trafficking. The power of laws in restraining individuals from committing illegal act cannot be denied. Laws relating to labour, migrants, and their enforcement enhances the ability of state parties to combat human trafficking. They are regarded as the best mode to eliminate the "supply and demand" in human trafficking. Government should make full use of its laws to prevent the crime effectively. In order to achieve the target, the legal framework must be clear. Sex trade, which is among the main forms of exploitation in human trafficking cases, is good for illustration. In order to fight human trafficking against those who are involved in sex trade the prohibition of prostitution must be made clear by all the governments in their policies and laws.

In Iran and Saudi Arabia, the laws of the two countries clearly declare that prostitution is a crime which is punishable by death. Such law will deter the trafficker from trafficking vulnerable people for prostitution. However, in Thailand, illegality of prostitution is arguable due to ambiguity of its laws. Its governing laws namely the Penal Code Amendment Act (No. 17) B.E. 2547 (2003), Prevention and Suppression of Prostitution Act, B.E. 2539 (1996), Entertainment Places Act of B.E. 2509 (1966) failed to prevent the sex trade in the country. ${ }^{8}$ Another example is as regards to discrimination. ${ }^{9}$ One of the major causes of trafficking of women is discrimination against women in employment and education. ${ }^{10}$ Under Article 26 of the International Covenant for Civil and Political Rights, states are

7 "The 3Ps: Prevention, Protection, and Prosecution," United States Department of State, accessed Nov 23, 2013, http://www.state.gov/ documents/organization/167334.pdf.

8 "Current Legal Framework: Prostitution in Thailand," International Models Project on Women's Rights, accessed Nov 25, 2013, http://www.impowr.org/content/current-legal-framework-prostitution-thailand.

9 United Nations. Human Rights and Poverty Reduction: A Conceptual Framework. Office of the High Commissioner for Human Rights, 2004.

10 Janic Chuang, "Beyond a Snapshot: Preventing Human Trafficking in the Global Economy," Indiana Journal of Global Legal Studies, 13 (2006): 27. 
obliged to refrain from discrimination practices and adopt punitive measures to ensure the equality and non-discrimination regardless of the gender. ${ }^{11}$ Therefore, an Optional Protocol to the Convention on the Elimination of Discrimination against Women (CEDAW) was adopted on 6th October 1999 to curb the discrimination issue. By ratifying the Optional Protocol, the state parties have recognized the competence of the CEDAW committee to monitor their compliance the Convention. It also gives rights to the victim to lodge complaints against a state member when her rights under CEDAW are violated. The CEDAW Committees will conduct an investigation against the state party in response to the complaint in order to protect the victim from being victimized on the basis of discrimination. ${ }^{12}$ In order to benefit from the Protocol, domestic law which incorporates the Protocol must be adopted and be enforced accordingly.

\section{"Second P": Protection of the Trafficking Victim}

Protection of the victim is very important. The victim is the source person who can give information about the crime to the government and helps the police in collecting evidence against the perpetrator. Therefore, a principle of non-punishment of the victim is introduced in some jurisdictions. For example, in the USA, the Trafficking Victims Protection Act (TVPA) entails the U. S Department of State to take this principle as a consideration before putting a country at any tier in Trafficking in Persons report to ensure that the victim is not to be treated as an accused person. ${ }^{13}$

This principle is in line with the Principle 7 of the Recommended Principles and Guidelines on Human Rights and Human Trafficking issued by the United Nations Office of the High Commissioner for Human Rights. It provides the responsibility of state parties to protect and assist the trafficking victim and not to treat the person as an offender.

11 International Covenant on Civil and Political Rights, G. A. RES. 2200, U. N. GOAR, $21^{\text {st }}$ Sess., Supp. No. 16, at 52, U. N. Doc, A6316 (Dec 16, 1966).

12 "Optional Protocol to the Convention on the Elimination of All Forms of Discrimination against Women," United Nation, accessed Dec 4, 2013, http://www.un.org/womenwatch/daw/cedaw/protocol/.

13 "Non-Criminalization of Victims for Crimes Committed in the Course of Being Trafficked," U.S Department of State, accessed Dec 2, 2013, http://www.state.gov/j/tip/rls/fs/2013/211629.htm. 
Trafficked persons shall not be detained, charged or prosecuted for the illegality of their entry into or residence in countries of transit and destination, or for their involvement in unlawful activities to the extent that such involvement is a direct consequence of their situation as trafficked persons. ${ }^{14}$

In order to ensure that the effective protection of the victims is executed, the "3Rs" principles which represent rescue, rehabilitation and reintegration are intensely introduced.

\section{First "R”: Rescue}

Rescue literally means 'to save someone from a dangerous or difficult situation'. ${ }^{15}$ It requires a skill to identify the victim and the trafficker. The skill is also crucial to ensure the victim receives a reasonable support and resource including shelter, medical assistance, work and safe house for the victims pending the completion of the trial against the perpetrator.

Guideline 2 of Recommended Principles and Guidelines on Human Rights and Human Trafficking put an obligation on the states members to use their due diligence in identifying the traffickers and the victims. Therefore, the guideline suggests that:

(i) The authorities and officials of the state members should have guidelines and procedures to precisely identify the trafficked persons. ${ }^{16}$

(ii) The authorities and officials of the state members should have appropriate training in the identification of the victims. ${ }^{17}$

(iii) The authorities, officials and non-governmental organizations in the state members should cooperate for the identification and assistance of victims. ${ }^{18}$

14 "Recommended Principles and Guidelines on Human Rights and Human Trafficking," Office of the High Commissioner for Human Rights, accessed Dec 2, 2013, http://www.ohchr.org/Documents/Publications/Traffickingen.pdf.

15 Oxford Dictionaries, accessed Nov 25, 2013, http://www.oxforddictionaries.com/definition/english/rescue?q=rescue.

16 Guideline 2(1), Recommended Principles and Guidelines on Human Rights and Human Trafficking.

17 Guideline 2(2), Recommended Principles and Guidelines on Human Rights and Human Trafficking.

18 Guideline 2(3), Recommended Principles and Guidelines on Human Rights and Human Trafficking. 


\section{Second " $R$ ": Rehabilitation}

Rehabilitation of a person can be defined as restoring him to his normal state by training and therapy. ${ }^{19}$ To rehabilitate the victims is not an easy task, especially when the victim suffers a psychological injury as a result of being tortured and being physically abused for a long period. In addition, he or she might be infected with various kinds of sexually transmitted infections (STIs) such as HIV and AIDS. In this situation, it is not that easy for most of the victims' families to accept them back.

To cater this rehabilitation problem, the state government should have rehabilitation centers that can be doubled up or be used as a temporary and institutional care to protect the victim. This center will be a good place for the victim to regain their strength to mingle with the community, which will help their rehabilitation process.

\section{Third " $R$ ": Reintegration}

Reintegrate can be defined as to integrate someone back into society ${ }^{20}$ or to integrate again into an entity. ${ }^{21}$ This is a process which follows the "rescue" principle and to pursue the criminal justice outcomes. ${ }^{22}$ This principle is linked to the rehabilitation process. Without reintegration, the return of the victim to his own country would expose him to the risk of being re-victimized and re-exploited as trafficking victims by the syndicate.

Article 8 of the Protocol to Prevent, Suppress, and Punish Trafficking in Persons, Especially Women and Children ${ }^{23}$ provides basic framework for reintegration of the trafficking victims.

Article 8 (1) of the Protocol requires State Parties to facilitate the repatriation of citizens or nationals with due regard for the safety of the victim without unreasonable delay. In this case,

\footnotetext{
19 Oxford Dictionaries, accessed November 25, 2013, http://www.oxforddictionaries.com/definition/english/rehabilitate.

20 Oxford Dictionaries, accessed November 25, 2013, http://www.oxforddictionaries.com/definition/english/reintegrate?q= reintegration\#reintegrate_14.

21 Merriam-Webster, accessed November 25, 2013, http://www.merriamwebster.com/dictionary/reintegrate.

22 Sanja Milivojevic and Marie Segrave, "Responses to sex trafficking: gender, boarder and home," 46.

23 United Nations Protocol to Prevent, Supress, and Punish Trafficking in Persons, Especially Women and Children, opened for signature 15 December. 2000, 2237 UNTS, Annex II.
} 
the state party must ensure that the safety of the victim is guaranteed if he or she is returned to their home state. If the victim is a child, the state party must satisfy that there is a trustworthy guardian who can take care and protect the child. ${ }^{24}$

(ii) Article 8 (2) state that three considerations must be taken by the state parties before repatriation or rehabilitation of the victim to his home country:

(a) the return shall be with due regard for the safety of that person;

(b) the status of the victim in any legal proceedings related to the trafficking case; and

(c) The repatriation shall preferably be voluntary.

(iii) Article 8 (3) provides that the state party must verify whether the victim is its national or had the right of permanent residence in its territory at the time of entry at the time the entry into the territory of the receiving State Party.

(iv) Article 8 (4) further states that in order to facilitate the return of a victim who has no proper documentation, the State Party must provide the necessary travel documents or other authorization as may be necessary to enable the victim to travel to and reenter his country.

In addition to this, the Protocol has been supported by Model Laws against Trafficking in Persons, provided by the United Nations Office on Drugs and Crime. ${ }^{25}$ The model can be regarded as a technical assistance to the state parties in adoption of laws, review, or amendment of the existing legislation in line with the international framework.

For example, Article 33 of the model law supports Article 8 of the Protocol. Both articles require state parties to repatriate the victims to his or her original country without unnecessary delay by providing them with the relevant travel documents, after considering their rights and safety. Article 33 further strengthens that the principle

24 New York. Legislative Guideline for the Implementation of the United Nations against Transnational Organized Crime and the Protocols Thereto. UNDOC, 2004.

25 "Model Laws and Treaties," United Nations Office on Drugs and Crime accessed Dec 10, 2013, http://www.unodc.org/unodc/en/legal-tools/modeltreaties-and-laws.html. 
of non-refoulement ${ }^{26}$ and of the prohibition of inhuman or degrading treatment for their safe return. The return of the victim should not be done if there is a tendency that the victim's life or his family will be endangered due to his return such as the risk to be detained and prosecuted by state authority. In addition, the Model $\mathrm{Law}^{27}$ requires that no record shall be made in the victims identity papers in relation to the reason for his return that may affect his right to leave or enter a country or that may lead to other negative consequences.

\section{"Third P": Prosecution of the Perpetrators}

The prosecution against the perpetrator of human trafficking is one of the effective approaches in preventing human trafficking at large. The United Nations in its written guidelines ${ }^{28}$ has outlined the needs of the UN members to take some extensive efforts in combating the crime which among others includes:

(i) The members should have legislation and laws for the offence of trafficking. ${ }^{29}$

(ii) The members should efficiently prosecute and resolve the trafficking. ${ }^{30}$

(iii) The members should provide proper sentence and punishment for the person who is found guilty of the trafficking offence. ${ }^{31}$

26 Non-refoulement is a concept which prohibits States from returning a refugee or asylum seeker to territories where there is a risk that his or her life or freedom would be threatened on account of race, religion, nationality, membership of a particular social group, or political opinion.

27 Article 32 of Model Laws against Trafficking in Persons, UNODC \& UN. GIFT (Vienna: United Nations, 2009).

28 "Recommended Principles and Guidelines on Human Rights and Human Trafficking," Office of the High Commissioner for Human Rights, accessed Dec 3, 2013, http://www.ohchr.org/Documents/Publications/Traffickingen.pdf

29 Criminalization, Punishment and Redress, No. 12, Recommended Principles and Guidelines on Human Rights and Human Trafficking.

30 Criminalization, Punishment and Redress, No. 13, Recommended Principles and Guidelines on Human Rights and Human Trafficking.

31 Criminalization, Punishment and Redress, No. 15, Recommended Principles and Guidelines on Human Rights and Human Trafficking. 
The U.S. State Department recommends that the state members should provide at least a maximum of four years imprisonments, ${ }^{32}$ to longer sentences based on the severity of their actions. The severity of punishment is not only for punishing the perpetrator, but to restrain others from committing the same offence. As for Australia, the offences relating to trafficking in children will carry a maximum penalty of (25) years' imprisonment. ${ }^{33}$

In addition, the success of the government in prosecuting also is vital since it will contribute to the position of the state in TIP report. In most of the cases, the prosecution failed to prove their case because the victims were uncooperative or they provided weak testimonies during the trial. ${ }^{34}$ There are some cases where the victims simply refused to identify the traffickers for fear of adverse repercussions which will endanger their families in their country of origin. To ensure success in prosecution, the prosecutors in some countries like the Philippines play active roles by involving themselves in human trafficking cases at the very beginning, either in investigation or prosecution stage. ${ }^{35}$ This is among the factors that contribute to their success in their case against the perpetrator since they have a good relationship with the victims.

\section{THE MALAYSIAN APPROACH IN COMBATING HUMAN TRAFFICKING}

International law is a powerful conduit for combating human trafficking. Instruments that deal with human trafficking can be traced back to the abolition of slavery. They include provisions within the Slavery Convention (1926) and the Supplementary Convention on the Abolition of Slavery, the Slave Trade, and Institutions and Practices

32 "The 3Ps: Prevention, Protection, Prosecution ," Office to Monitor and Combat Trafficking in Persons Washington DC, accessed December 8, 2016, http://www.state.gov/documents/organization/167334.pdf.

33 Section 2271.4 and 271.7, Australia Criminal Code Act 1995.

34 P.R Gunarajan a/l Ramayal, "Organised Crime: Government Initiatives, Laws and Investigation of Human Trafficking in Person and Smuggling of Migrants in Malaysia" (paper presented at International Conference on Trafficking for World Youth Foundation, Malacca, September 3-7, 2013).

35 World Youth Foundation, "Group Presentation on Human Trafficking" (paper presented at International Conference on Trafficking for World Youth Foundation, Malacca, September 3-7, 2013). 
Similar to Slavery (1956). Additional tools of international law that include segments against the trafficking of persons includes the Universal Declaration of Human Rights (1948), the International Covenants on Civil and Political Rights (1966), The United Nations Convention for the Suppression of the Traffic in Persons and of the Exploitation of the Prostitution of Others (1949), and the Convention on the Elimination of all Forms of Discrimination Against Women (CEDAW) (1979). These instruments laid the foundation for the contemporary conventions and efforts to eliminating trafficking. The most reputable and recent instruments of international law that have set the course on how to define, prevent, and prosecute human trafficking are the United Nations Convention against Transnational Organized Crime and its two different but related protocols namely the United Nations Protocol to Prevent, Suppress, and Punish Trafficking in Persons, Especially Women and Children, and the United Nations Protocol against the Smuggling of Migrants by Land, Sea, and Air.

Malaysia has not ratified any of the above treaties and protocols above except CEDAW. Nevertheless, Malaysia is in the position to "accede" the UN TIP Protocol in the near future. Malaysia's decision to sign the ASEAN Declaration against Trafficking in Persons Particularly Women and Children on 29 November 2004 in Vientiane, Laos has shown its commitment as an ASEAN member country to combat the crime, thus towards ratification of the protocol. ${ }^{36}$ The subsequent part of this article analyses whether Malaysia's response to international human trafficking laws are in compliance with the "3Ps" approaches in combating human trafficking.

\section{"First P": Prevention of Human Trafficking}

Malaysia has established the legal framework to combat human trafficking to fight the crime in the country. Malaysia has proven its seriousness in addressing the problem by passing the Anti-Trafficking in Persons and Anti-Smuggling of Migrants Act 2007 (ATIPSOM 2007). This Act is supported by the Federal Constitution of Malaysia,

36 Datuk Ahmad Fuad Ab Aziz, speech given at The Vienna Forum for United Nations Global Initiative to Fight Human Trafficking, Vienna, Austria 2008, accessed August 13, 2004, http://www.ungift.org/docs/ungift/pdf/vf/ statements/Malaysia.pdf. 
which is the supreme law of the country and eleven legislation namely the Immigration Act 1959/63 [Act 155], Malaysian Maritime Enforcement Agency Act 2004 [Act 633], Customs Act 1967 [Act 235], Evidence Act 1950 [Act 56], Court of Judicature Act 1964 [Act 91], Child Act 2001 [Act 611], Penal Code [Act 574], Anti-Money Laundering and Anti-Terrorism Financing Act 2001[Act 613], Prevention of Crime Act 1959 [Act 297], Extradition Act 1992 [Act 479] and Mutual Assistance in Criminal Matters Act 2002 [Act 621].

In addition to these laws, the Malaysian Anti-Trafficking National Action Plan (NAP) was introduced in 2012. Through NAP, the government of Malaysia has planned to conduct its public awareness programs on trafficking in persons through educational programs where the campaigns on the danger of the crime are conducted through its electronic media. As a result, Malaysia is reported to have done more than 5,500 public service announcements on human trafficking via its national and state radio. ${ }^{37}$

\section{"Second P": Protection of the Trafficking Victim}

Malaysia has made various efforts through its laws to protect the victims. The law requires enforcement officers to save and protect any potential exploited victim. Prompt action shall be taken once they received information, ${ }^{38}$ complaint or report ${ }^{39}$ regarding the victim. The investigating officer will record the victim's or witness's statement in accordance with the power given under Section 34 of the ATIPSOM 2007. The officer also shall bring the victim for medical examination or treatment. ${ }^{40}$ In case where the victim is hospitalized, it is the duty of the enforcement officer to secure and protect the victim from any danger. ${ }^{41}$

Once the victim is rescued, the enforcement officer shall apply for an Interim Protection Order (IPO) from a Magistrate within (24)

37 "Trafficking in Persons Report 2013," U.S. Department of State, accessed December 4, 2013, http://www.state.gov/documents/ organization/210740.pdf.

38 Information might be received through oral information, phone call, a piece of paper, or from an informant.

39 Section 107 of Criminal Procedure Code [Act 593] requires crime to be reported.

40 Section 45 of Anti-Trafficking in Persons and Anti-Smuggling of Migrants Act, 2007 (Act No. 2 of 2007).

41 Section 48 of Anti-Trafficking in Persons and Anti-Smuggling of Migrants Act, 2007 (Act No. 2 of 2007). 
hours as mentioned under Section 44 (1) of the Act. If the Magistrate is satisfied that the victim is a trafficked person, he shall make an IPO for the victim to be placed in the adult women shelter home, adult male shelter home or children shelter home for (14) days for the purpose of an investigation by the enforcement officer. ${ }^{42}$ After the investigation, the victim will be placed in the shelter for a certain period if the Magistrate is satisfied that the victim is trafficked and is required to give evidence in the prosecution case. The local victim might be placed at the shelter up to (2) years. For a foreign victim, he might be placed at the shelter for (3) months and subject to be extended if necessary. ${ }^{43}$ While in the shelter, the victim's need and welfare such as food, shelter, and safety will be provided.

The government of Malaysia also adopts a "voluntary repatriation" approach. This approach is in line with the international practice and human rights law which gives the rights for the victims to return to their origin countries voluntarily. The process will be managed by Malaysia in cooperation with trafficked persons' country embassies. In the TIP report $2014,{ }^{44}$ the US State Department acknowledged Malaysian effort in protecting the labour trafficking victims by allowing some of them to stay and work in Malaysia.

\section{"Third P": Prosecution of the Perpetrators}

The government of Malaysia has made some progress in its law enforcement against human trafficking by enacting laws and prosecuting the offenders. Trafficking in Persons report $2013^{45}$ reported that there is an increasing number of cases investigated, prosecuted and convicted in 2013 compare with 2012.The prohibition of all forms of exploitation in human trafficking is done through AntiTrafficking in Persons and Smuggling of Migrants 2007 which provides severe punishment for the offender. The Act provides

\footnotetext{
42 Section 44 (2) of Anti-Trafficking in Persons and Anti-Smuggling of Migrants Act, 2007 (Act No. 2 of 2007).

43 Section 51 (3) of Anti-Trafficking in Persons and Anti-Smuggling of Migrants Act, 2007 (Act No. 2 of 2007).

44 "Wisma Putra disappointed over US Trafficking in Person report 2014," New Straits Times Online, June 23, 2014, accessed June 23, 2014, http://www.nst.com.my/node/5250.

45 "Tier Placements- trafficking in Person Report 2013," U.S. Department of State, accessed December 13, 2013, http://www.state.gov/j/tip/rls/ tiprpt/2013/210548.htm.
} 
maximum life imprisonment of 20 years and fine RM1 million for the trafficking offence. It is viewed that the term of punishment is equally stringent if not more stringent especially when it is compared to those prescribed for other serious offenses in Malaysia such as rape. ${ }^{46}$

\section{EVALUATION OF THE MALAYSIAN APPROACH IN TIP REPORT}

In spite of Malaysia's compliance to the international legal framework and the "3Ps" approach, it is continuously being criticized for its ineffectiveness in making sufficient progress and improvement in areas of prosecution, prevention and protection. ${ }^{47}$ The major criticism is regarding the protection of the victim. On this matter, Malaysia is criticized for not fully complying with minimum standards. ${ }^{48}$ The report claims that Malaysia has not made a tangible improvement to its system in identifying and protecting the victim. The front-line enforcement officers also failed to recognize the human trafficking indicators which lead the victims remaining unidentified and subject to be punished under the national law i.e. immigration law especially for illegal overstaying.

Malaysia has also been alleged as having treated trafficking victims as criminals. It is said that a suspected criminal who is under arrest seems to enjoy greater freedom than a trafficking victim under protection. As mentioned earlier, once the victim is saved, he will be placed under 24-hour custody of the police. If the IPO is granted, he will be placed at government shelter for a certain period of time and his freedom is restricted. The difference between the victim and the perpetrator is that the latter has the choice to be freed once he pays the bail after being charged in court. Even the perpetrator is locked up, he can still have contact with the world outside via mail, telephone and receive visits by family members, friends and defense counsels. However, all these are not available to the victims under the

\footnotetext{
46 "Trafficking in Persons Report July 2015," U.S Department of State, accessed November 29, 2015, https://www.state.gov/documents/organization/245365.pdf.

47 "Wisma Putra disappointed over US Trafficking in Person report 2014," New Straits Times Online, June 23, 2014, accessed June 23, 2014, http://www.nst.com.my/node/5250.

48 "Trafficking in Persons Report 2013," U.S. Department of State, accessed December 4, 2013, http://www.state.gov/documents/ organization/210740.pdf.
} 
IPO who are detained in shelter home such as the right of movement and the right to be employed. They are only allowed to go out of the shelters accompanied by the respective officers for the purpose of giving testimony in court, hospital visit or other procedural matters. The TIP report in $2015^{49}$ make the same comment. Although the Malaysian government continued to provide assistance to foreign victims housed in government facilities for (1) to (6) months while under the IPO, these victims' freedom of movement is still limited and could not work outside the facilities.

It is reported that during the investigation and prosecution process, the victims have been poorly treated and no incentives such as goods or money were given to them. Such a situation puts them under emotional and psychological stress. Their poor treatment caused a riot to happen on 14 December 2009 at Women Home Shelter at Bukit Ledang, Kuala Lumpur. It was caused by the dissatisfaction of a few Indonesian women on the extension of their three (3) months Interim Protection Order. ${ }^{50}$ The situation becomes worse when the government facilities are not supported by medical officers or trained psychologist. These are among the reasons why the victims refuse to give testimony in court. They prefer to be a criminal and being punished under Immigration Act 1959/63 rather than be a witness to trafficking case which will indirectly cause them to receive a severe 'punishment'. If they were charged under the Act, they will be deported after serving an imprisonment which may be less than a year.

The Malaysian government has also been criticized in the TIP report for its actions which instead of preventing the crime, caused it to increase. The government policy in 2013 which shifted the responsibility to pay for the immigration costs and employment processing fees from the employer to the foreign worker has caused unnecessary problems. This new policy has trapped the victims into the usurious debt which tie them to debt-bondage with the trafficker. In 2015, it is reported that there is a large number of refugees in Malaysia including Rohingyas and Filipino Muslims who lacked formal status or the ability to obtain legal work permits in Malaysia.

\footnotetext{
49 "Trafficking in Persons Report July 2015," U.S Department of State, accessed November 29, 2015, https://www.state.gov/documents/organization/245365.pdf.

50 Umar Saifuddin bin Jaafar, "Cabaran Perlaksanaan Seksyen 52 Akta Anti Pemerdagangan Orang 2007," Attorney General Chambers, accessed July 17, 2012, http://agc-blog.agc.gov.my/agc-blog/?p=171\#more-171.
} 
Such situation put them in a vulnerable position and as they could easily become the prey of human traffickers such as by seeking loans illegally from loan sharks. ${ }^{51}$ Another issue is as regards to the deportation of the loan victim. According to the report, ${ }^{52}$ after the victims finished giving testimony in court, the government discontinued its policy of treating trafficked victims by transferring them to detention facilities for deportation, which are managed by the Immigration Department as if they are criminals.

Furthermore, there are complaints from the public and NGOs regarding the involvement of the officers, especially from the Maritime and Immigration Departments in managing the trafficking of the victims from other countries. They are involved in providing fake documents and helping the illegal migrants to enter and stay in Malaysia without any legal documents. There were allegations that government officers involved in the trafficking activities and that the Malaysian government failed to take action against the corrupt officers. There was a case where the Malaysian government has carried out an investigation on an immigration officer. He was arrested in July 2009 for an alleged involvement in trafficking Burmese citizens to Thailand. However, the case was ended in an acquittal since the officer was found not guilty. ${ }^{53}$

Among the changes and law reform proposed is the amendment of the anti-trafficking law to allow trafficking victims to travel, work, and reside outside government facilities, including while under protection orders pending the completion of the prosecution of the traffickers. Apart from amending the law, enforcement agencies need to be effective and efficient in enforcing existing laws. Efforts to arrest, investigate, prosecute, convict, and punish traffickers, including complicit officials, need to be increased significantly. The law prohibiting employers from confiscating passports needs to be enforced strictly.

Methods to identify victims need to be improved and proper procedure to identify labour trafficking victims among vulnerable

\footnotetext{
51 "Trafficking in Persons Report July 2015," U.S Department of State, accessed November 29, 2015, https://www.state.gov/documents/organization/245365.pdf.

52 "Trafficking in Persons Report 2012," U. S. Department of State, accessed December 5, 2013, http://www.state.gov/j/tip/rls/tiprpt/2012/192367.htm.

53 "Pemerdagangan Orang: Pegawai Imigresen Kekal Bebas," Sinar Harian, June 25, 2013, accessed December 8, 2016, http://www.sinarharian. com.my/pemerdagangan-orang-pegawai-imigresen-kekal-bebas-1.175683.
} 
groups, such as migrant workers must be implemented. Migrant workers need to be educated of their rights, legal recourses, and remedies against traffickers. Labour inspections must also be increased and strengthened to identify instances of forced labour. Victims must be provided with equal opportunity to receive protective services that are not contingent on their participation in prosecutions against traffickers. As regards to prosecution there is a need to expand implementation of the directive requiring prosecutors to prepare victims for judicial proceedings at least two weeks prior to trial.

In order for the laws and policies to be implemented effectively, law enforcement and judicial officials need to be increased and be given proper training on how to effectively address all trafficking cases, including the identification of labor trafficking victims and employing a more victim-centered framework. On the same note, a dedicated and sufficient budget to the National Anti-Trafficking and Anti-Smuggling of Migrants Council (MAPO) must be provided. There is also an urgent need to increase transnational cooperation with other governments on enforcing anti-human trafficking laws.

\section{CONCLUSION}

There is no doubt that government of Malaysia is combating illicit criminal activities. It has ratified the Trafficking Protocol, adopting the "3Ps" approach, introduced the Anti Trafficking in Persons and Smuggling of Migrants Act 2007, and taken commendable efforts to prevent the crime, protect the victim, and punish the wrongdoer. Yet there are still serious issues in its efforts in fighting the crime, which needs more concerted attention, which is why, in the TIP Report the US Department of State has continuously placed Malaysia in a rather discouraging position. In 2014 United States (US) State Department has downgraded Malaysia to Tier 3 from the previous standing of the Tier 2 Watch List. $^{54}$ The 'unsafe' position put Malaysia at risk because it may be subject to sanctions under the William Trafficking Victims Protection Reauthorization Act $2008 .^{55}$ Consequently,

\footnotetext{
54 "Wisma Putra disappointed over US Trafficking in Person report 2014," New Straits Times Online, June 23, 2014, accessed June 23, 2014, http://www.nst.com.my/node/5250.

55 "Trafficking in Persons Report 2011," U.S Department of State. Accessed May 10, 2013, http://www.state.gov/j/tip/rls/tiprpt/2011/164222.htm.
} 
Malaysia may face sanctions from the U.S government where the latter may withhold or withdraw non-humanitarian and non-traderelated foreign assistance to Malaysia. Although the position has changed to Tier 2 Watch List in 2015, there is no guarantee that Malaysia would not be downgraded again. Therefore, the government of Malaysia should take extensive efforts in combating the crime especially in improving the welfare of the victims by allowing them to move freely, to work, not to be borne with their immigration costs pending the completion of the trial, and to ensure that the prospect of getting the traffickers convicted is assured. It is also recommended that the government of Malaysia give more protection to the trafficking victim by reforming its legal approach such as by providing a comfortable shelter to the victim, giving them freedom to work, and by supporting their physical and emotional needs. These enhancements should be done together with other service providers and NGOs to ease the government's burden and to find the best solution in eradicating human trafficking. 